Joanna JAROSZYK

Uniwersytet Mikołaja Kopernika, Toruń

\title{
Idea Wspólnego Europejskiego Domu a egoizmy narodowe i regionalne: przykład Hiszpanii
}

Koncepcja Wspólnego Europejskiego Domu, sformułowana w 1987 r. Sowieckiego wobec Europy Zachodniej straciła już swój niepokojący wydźwięk, związany z hasłem Sowieckiego Biura Politycznego „zdławić w uścisku, zdusić w objęciach”. Obecnie idea ta obejmuje różne modele integracji państw europejskich, wyrażając zarówno nadzieje jak i obawy uczestników tego procesu. Integracja gospodarcza i polityczna państw europejskich jest procesem ciagłym i dynamicznym, a pytanie o jej dalszy kierunek stało się szczególnie istotne wobec francuskiego „non” dla Konstytucji Europejskiej. W tym kontekście ponownie ożyły spory wokół istniejących modeli integracji, koncentrujące się wokół antagonistycznych koncepcji Europy Federalnej i Europy Ojczyzn w ujęciu konfederacyjnym. Niestety, dyskusja na temat przyszłego kształtu Europy pomija niezwykle istotny, ściśle związany z zagadnieniem integracji proces regionalizacji zachodzącej wewnątrz państw europejskich. Tymczasem poważna i merytoryczna dyskusja nad kształtem przyszłej Europy tego aspektu pomijać nie może. Wzrost znaczenia regionów i oczekiwania ich mieszkańców mogą bowiem wyznaczać przyszłe kierunki integracji.

Ma to szczególne znaczenie dlatego, że paralelnie do procesu europeizacji ${ }^{1}$, postępował proces regionalizacji wewnątrz narodowych państw europejskich. Regionalizacja, wynikająca przede wszystkim z żądań ,,autonomistów", czasem inicjowana była przez rządy państw, w ramach procesu decentralizacji. Obecnie regiony europejskie zwiększyły swe znaczenie ekonomiczne, uzyskały większe prawa i władzę wewnątrz państwa, w konsekwencji aspirując do bycia samodzielnymi podmiotami globalizacji i europeizacji.

${ }^{1}$ Czyli integracji UE, która może przerodzić się w szczególny proces polityczny $z$ tworzeniem organizmów ponadnarodowych wyposażonych we władzę i coraz szersze kompetencje. 
Przykładem tego procesu jest Hiszpania, w której po 40-letnim okresie dyktatury frankistowskiej, odrzucającej jakąkolwiek formę autonomii regionalnej od 1975 r. rozpoczął się powolny proces demokratyzacji. Konstytucja z 1978 r. uznała „narodowości historyczne” Katalonii, Kraju Basków i Galicji i przyznała im prawo do autonomii, choć jednocześnie zgodnie z art. 2 Ustawy Zasadniczej opiera się ona na nierozerwalnej jedności Narodu hiszpańskiego. W wyniku procesu decentralizacji powstało 17 Wspólnot Autonomicznych, a Hiszpania stała się jednym z najciekawszych przykładów państwa regionalnego (choć trzy narodowości historyczne odrzucają termin „region”) ${ }^{2}$. Co warto podkreślić; nowy podział terytorialny i nowe instytucje obudziły, lub wręcz stworzyły świadomość i identyfikację regionalną w całej Hiszpanii, również w miejscach, gdzie wcześniej nie występowała. Ruchy i partie regionalne i nacjonalistyczne, które posiadały długoletnią tradycję jedynie w Katalonii i Kraju Basków zaczęły pojawiać się również $\mathrm{w}$ innych regionach, pełniąc ważną rolę w parlamentach regionalnych czy nawet koalicjach rządowych.

Proces tworzenia hiszpańskiego systemu autonomii regionalnych przebiegał w trzech fazach. Pierwsza obejmuje okres od powołania rządu Adolfo Suareza w czerwcu 1976 r. do uznania Konstytucji w grudniu 1978 r. Suarez, który traktował priorytetowo kwestię regionalną zawarł porozumienie z katalońskim przywódcą Josepem Tarradellasem, dotyczące przywrócenia „Generalidad” (rządu) Katalonii, mianując go prezydentem. Nie udało się natomiast znaleźć podobnego przywódcy w Kraju Basków, gdyż przywódcy PNV (Baskijskiej Partii Nacjonalistycznej) uzależniali rozpoczęcie jakichkolwiek negocjacji od uwolnienia więźniów politycznych, w tym również terrorystów, z czym Suarez zwlekal. W połowie $1977 \mathrm{r}$. zainicjowano tzw. „,preautonomie”, przypisując rzekome dążenie do samorządu wszystkim regionom Hiszpanii. Sądzono przy tym, że dzięki

2 Pojawiają się jednak głosy, że Hiszpanii nie można identyfikować z państwem regionalnym (egionów) z dwóch względów: ponieważ podmiotami autonomii mogą być zarówno narodowości, jak i regiony; oraz dlatego że Hiszpania posiada pewne elementy federacji. Nie można jej za taką uznać, ponieważ Wspólnoty Autonomiczne nie posiadają prawa do samostanowienia (tworzenia konstytucji), co jest najważniejszą cechą federacji. Dlatego można uznać, że hiszpański model państwa znajduje się gdzieś pomiędzy państwem regionalnym a federalnym, odpowiadając jednak filozofii pierwszego. Por. E. Alvarez Conde, El regimen politico espanol, Wyd. Tecnos, Madryt 1984 , s. 59.

3 V. M. Perez-Diaz, Powrót społeczeństwa obywatelskiego w Hiszpanii, Wyd. Znak, Kraków 1996, s. 220. 
ustanowieniu powszechnego systemu zmniejszy się wagę problemu katalońskiego i baskijskiego, a regionalną klasą polityczną można będzie manipulować.

Artykuł 2 i Rozdział VIII Konstytucji ujmuje sprawę autonomii zgodnie z doświadczeniami okresu ,preautonomii”, opierając koncepcję państwa na czterech podstawowych zasadach:

- zasadzie nierozerwalnej jedności narodu hiszpańskiego i istnieniu wspólnej i niepodzielnej ojczyzny wszystkich Hiszpanów;

- zasadzie prawa do autonomii;

- zasadzie solidarności;

- zasadzie współpracy ${ }^{4}$.

Pierwsza $\mathrm{z}$ wymienionych zasad ma największe znaczenie, gdyż wskazuje na jednolity charakter państwa hiszpańskiego - nie jest to więc federacja - a poszczególne regiony nie dysponują prawem do secesji. $\mathrm{W}$ art. 145 ustrojodawca sformułował zakaz tworzenia federacji wspólnot autonomicznych, a nadto w ust. 2 zobowiązał wspólnoty do statutowego określania zasad współpracy. Jednocześnie art. 150.2 przewiduje możliwość delegacji władzy ogólnonarodowego państwa na wspólnoty. W rzeczywistości rozdział VIII Ustawy zasadniczej stanowił kompromis nierozstrzygający problemu skutecznego przekazywania uprawnień autonomicznych społecznościom i pozostawiający decyzję w tej sprawie późniejszym negocjacjom politycznym ${ }^{5}$. Konstytucja została uchwalona przez parlament i zatwierdzona w referendum w 1978 r. Baskijska PNV nawoływała do bojkotu referendum, gdyż Konstytucja wbrew ich żądaniom nie wspominała o pierwotnych ,historycznych prawach”, co umożliwiałoby późniejsze negocjacje w sprawie uzyskania prawa do samostanowienia. PNV uznała Konstytucję dopiero wtedy, gdy żądane przez nią klauzule znalazły się w Statucie Baskijskim z grudnia 1979 r.

Druga faza regionalizacji trwała od przyjęcia Ustawy Zasadniczej do próby zamachu stanu w $1981 \mathrm{r}$. Okres ten cechowały dwa paralelne procesy. W 1979 r. dyskutowano i uchwalono statut baskijski i kataloński. Suarez

4 A. Łabno-Jabłońska, Iberyjska droga do demokracji, Wyd. Sejmowe, Warszawa 1996, s. 45.

5 Wspomnieć przy tym należy, że Konstytucja przewiduje różne typy autonomii, w zależności od tego, czy powołują się one na art. 151 (Katalonia, Kraj Basków, Galicja i Andaluzja), czy też na art. 143, nie mówiąc już o osobliwości statutu Nawarry i szczególnym charakterze umów gospodarczych tego regionu z władzami centralnymi oraz terytorium baskijskim. Por. V. M. Perez Diaz, op. cit., s. 221. 
musiał stawić czoła projektom statutów stworzonych przez nacjonalistów (Statut z Guerniki i Sau), które redukowały uprawnienia władz centralnych do absolutnego minimum, a nawet ograniczały swobodę działania w sprawach polityki zagranicznej ${ }^{6}$. Drugi, paralelny proces obejmował resztę kraju i dotyczył aktywizacji świadomości regionalnej innych obszarów. Wypływało to z dwóch źródeł. Pierwszym było podejrzenie, że specjalne traktowanie Basków i Katalończyków odbije się niekorzystnie na pozostałych. Między regionami występowało wiele różnych konfliktów dotyczących podatków, inwestycji, energii, surowców naturalnych itp. Po drugie, z tym dążeniem do skorygowania nierówności ekonomicznych łączyło się roszczenie do równości statusów. Niektórzy nie mogli się pogodzić z tym, że pewne regiony (Katalonia, Kraj Basków i Galicja) miałyby zyskać całkowitą autonomię, a inne tylko częściową, że pewne regiony miałyby dojść do niej szybko, a inne powoli i z trudnością (co sugerowały art. 143 i 151 Konstytucji). W efekcie w referendum z lutego 1980 r. Andaluzyjczycy odrzucili rządową propozycję niepełnej autonomii dla tego regionu. Od tego czasu współzawodnictwo o prestiżowy status narodowości rozgorzało w całym kraju, przy czym (jak podkreśla Perez-Diaz), trudno powiedzieć, czy uczucia mas były autentyczne, czy też stanowiły wyłącznie projekcję regionalnych klas politycznych. Te wydarzenia, jak również intensyfikacja zamachów terrorystycznych ETA (których działania zyskały poparcie $15 \%$ wyborców) spowodowały niepokój w wojsku, którego kulminacją była próba zamachu stanu w lutym $1981 \mathrm{r}$.

Trzecią fazę regionalizacji rozpoczął właśnie ten zamach. W wyniku mediacji króla Juana Carlosa de Bourbon i negocjacjom z siłami zbrojnymi wojsko stłumiło zamach. Jak twierdzi Perez-Diaz, jego strategia była jasna: siły zbrojne w sposób niedwuznaczny powiadomiły klasę polityczną, że wymuszą od niej moralne zobowiązanie do nadania priorytetu zachowaniu jedności i terytorialnej integralności Hiszpanii. Porozumienie to pociągało za sobą zwolnienie procesu przekazywania uprawnień regionom autonomicznym, ograniczenie nacjonalistycznej retoryki z separatystycznymi akcentami i narzucenie prawnych ram, które chroniłyby władzę

6 W końcu osiagnięto porozumienie, którego istotę stanowiła niezwykle ogólnikowa deklaracja przyznająca wyłączne uprawnienia rządom autonomicznym, zawierająca jednak ostrzeżenie w postaci dwuznacznej klauzuli, „które jednak nie mogą naruszać uprawnień dotyczących tych samych spraw, przekazanych przez Konstytucję, w sposób równie wyłączny, centralnym władzom państwa”. Por. ibidem, s. 221-222. 
rządu centralnego. Groźba zaowocowała porozumieniem głównych sił politycznych, które opracowały nowe prawo (LOAPA - Prawo Organiczne Dotyczące Procesu Harmonizowania Procesu Autonomizacji), stanowiące model dla szeregu statutów regionalnych uchwalanych w następnych latach (mimo jego zakwestionowania przez Basków i Katalończyków przed Trybunałem Konstytucyjnym, który orzekł ich sprzeczność z Konstytucją w 1983 r.). W rezultacie zawarto serię paktów pomiędzy władzą centralną i różnymi regionalnymi elitami politycznymi. Składają się na nie: rozdział VIII Konstytucji, statuty kataloński i baskijski z 1979 r. oraz uchwalone później pozostałe statuty różnych regionów czy też grup narodowościowych. Do tego zbioru ogólnych norm dodać trzeba te instytucje, które regulują proces stałych negocjacji dotyczących efektywnego przekazywania zasobów władzom regionalnym przez administrację centralną ${ }^{7}$. Dzięki paktom regionalnym z pewnością udało się wzmocnić narodową integrację. Do systemu politycznego udało się włączyć niemal wszystkie ruchy regionalne i dużą część peryferyjnych ruchów nacjonalistycznych. Baskijska PNV, choć ciągle trzymająca się obrzeży systemu politycznego objawiła pewną gotowość do współpracy z rządem centralnym, czego wyrazem był ograniczony prawny pakt zawarty między prezydentem autonomicznego rządu baskijskiego, Jose Antonio Ardanzą i baskijskimi władzami PSOE. Nie zmienia to faktu, że PNV stale odwołuje się do potrzeby ostatecznej renegocjacji statutu.

Dzięki regionalizacji panorama systemu partyjnego uległa poszerzeniu o ugrupowania regionalne, prezentujące zróżnicowane interesy Wspólnot w Kortezach. Wymienić należy przede wszystkim nacjonalistyczną, katalońską Konwergencję i Unię (CiU), Republikańską Lewicę Katalonii (ERC), Baskijską Partię Nacjonalistyczną (PNV), Solidarność Baskijską (EA) czy Galicyjski Blok Nacjonalistyczny (BNG). Na uwagę zasługuje tradycyjnie wciąż mocna - choć ostatnimi czasy jednak słabnąca - pozycja nacjonalistycznej CiU oraz wyraźnie zyskująca na poparciu lewica republikańska z ERC; to ostatnie ugrupowanie - nie tylko w 2004 r. - wyraźnie poprawiło swój wynik wyborczy, ale także - jeszcze w roku poprzednim - umocniło swoją pozycję w Katalonii, wchodząc nawet do koalicyjnego rządu lewicy.

Okazało się jednak, że obecność ERC w Kortezach - jak również innych partii typowo regionalnych (a zwłaszcza lewicowych) - może spo-

${ }^{7}$ Ibidem. 
wodować destabilizację hiszpańskiego systemu politycznego. Wynika to przede wszystkim ze słabości parlamentarnej PSOE Jose Luisa Rodriqueza Zapatero, która w wyborach z marca 2004 r. uzyskała 164 miejsca w Kortezach, liczących 350 deputowanych. Socjaliści zdecydowali się wówczas rządzić samodzielnie, zawierając z innymi siłami umowy dotyczące konkretnych kwestii. Niepokój budził zwłaszcza fakt, że jeszcze przed zwycięskimi wyborami socjaliści zawarli trójstronny pakt dotyczący rządów w Katalonii z radykalną Esquerra Republicana de Catalunya, oraz z komunistami i ekologami z Iniciativa per Catalunya. Rząd katalońskich socjalistów zależał z kolei od sił, które żądały niepodległego państwa katalońskiego. Te dwie siły, obok partii baskijskich i kanaryjskich stanowiły dla socjalistów główne siły poparcia w trakcie minionej kadencji parlamentu hiszpańskiego. Sytuacja ta zaowocowała rozpoczęciem procesu reformy konstytucyjnej, której domagały się siły nacjonalistyczne chcące zwiększyć stopień swojej samorządności, a która stanowi zagrożenie dla terytorialnej integralności Hiszpanii. Reformę wymuszali na socjalistycznym rządzie jego partnerzy, wykorzystujący słabość gabinetu. Dlatego już sam pomysł zmiany konstytucji budził spore kontrowersje, zwłaszcza wśród zwolenników Partii Ludowej (PP), których w wyborach z 2004 r. i 2008 r. było ponad dziesięć milionów. Z dużym sprzeciwem spotkało się zwłaszcza żądanie baskijskich i katalońskich nacjonalistów, popieranych przez socjalistów rządzących w Katalonii, by konstytucja uznała historyczny charakter wspólnot autonomicznych Katalonii, Kraju Basków i Galicji, nadając im wyższą rangę w stosunku do pozostałych 14 hiszpańskich regionów. Jak pisze Hermann Tertsch, baskijscy i katalońscy nacjonaliści pokazali już jasno, że ich celem jest zniesienie wszelkich kompetencji państwa hiszpańskiego w Kraju Basków i w Katalonii i bezpośrednie stosunki z Brukselą. Nienacjonalistycznych mieszkańców Baskonii i Katalonii niepokoiła przy tym gotowość rządu w Madrycie do ustępstw wobec tych, którzy chcą zatrzeć wszelki ślad wspólnej hiszpańskiej historii ${ }^{8}$. Doprowadziło to do pierwszych starć w łonie samej Partii Socjalistycznej, której przewodniczący i premier rządu Andaluzji Manuel Chaves wyraził już swoje odmienne od kolegów z Katalonii zdanie. Oznacza to, że ważny sektor Partii Socjalistycznej odciął się od inicjatywy reformy konstytucyjnej ${ }^{9}$.

8 Hermann Tertsch (tłum. Katarzyna Górna), „Gazeta Wyborcza” z 7 listopada $2004 \mathrm{r}$.

9 Ramon Perez-Maura (thum. Katarzyna Górna), „Gazeta Wyborcza” z 10 października 2004 r. 
Tymczasem w ciągu ostatnich lat doszło do eskalacji żądań regionalistów. Pod koniec kwietnia 2005 r. kataloński rząd zażądał całkowitej suwerenności finansowej oraz radykalnego ograniczenia dochodów odprowadzanych do budżetu centralnego. Co więcej, wezwał Katalończyków do mobilizacji w celu „pogrzebania” dotychczasowego samorządu prowincji po to, by skuteczniej pertraktować z Madrytem. Kataloński minister finansów i gospodarki Antoni Castells stwierdził wprost: „trzeba skończyć ze zwierzchnością państwa, które samo ustala, ile i komu dać. Autonomie weszły w wiek dojrzały. Dochody muszą zależeć od podatków płaconych przez ich obywateli, a nie od tego, ile zechce przyznać im państwo. Hiszpania musi się pogodzić z tym, że zmierzamy w stronę federacji”. Tak twardy kurs Katalończycy przyjęli od stycznia 2004 r., w którym powstał nowy koalicyjny rząd kataloński socjalisty Pasquala Maragalla, do którego weszli także, po raz pierwszy od ustanowienia autonomii, Lewica Republikańska ERC oraz postkomuniści. To był przełom, utraciła bowiem wówczas władzę partia umiarkowanych nacjonalistów CiU premiera Jordi Pujola, rządzącego autonomią od samego początku, tj. od 1980 r. Pujol w czasie swej wieloletniej działalności politycznej walczył z rządem w Madrycie o pieniądze, ale tematu samostanowienia, nie mówiąc o niepodległości, unikał ${ }^{10}$.

Tymczasem już w październiku 2005 r. parlament kataloński (w tym lokalna partia socjalistyczna), przegłosował zwiększenie autonomicznej władzy Katalonii. Nowy statut określa Katalończyków jako „naród” istniejący wewnątrz ,państwa wielonarodowego i federalnego”, a także podkreśla „prawo Katalończyków do swobodnego decydowania o swojej przyszłości”. Te postanowienia okazały się najbardziej sporne, przeczą bowiem konstytucji, która definiuje Hiszpanów jako „naród niepodzielny". Dla radykalnych nacjonalistów dwóch z trzech partii, które statut przegłosowały, wymienienie narodu ma zasadnicze znaczenie, bo wskazuje, że źródłem prawa w Katalonii jest suwerenny naród kataloński. Nie przypadkiem przywódca nacjonalistycznej lewicy Josep Lluis Carod Rovira podkreślał w swoich wystąpieniach w parlamencie w Barcelonie, że statut to „pierwszy krok w stronę niepodległości Katalonii”.

Najpoważniejsza zmiana dotyczyła jednak pieniędzy i prawa. Katalonia miałaby sama zbierać wszystkie płacone tu podatki i oddawać Madrytowi tyle, ile uzna za stosowne. Taki system istnieje tylko w autonomicznym

10 Maciej Stasiński, „Gazeta Wyborcza” z 5 maja 2005 r. 
Kraju Basków; wszędzie indziej to hiszpański fiskus zbiera podatki i oddaje regionom część na ich potrzeby. Siedmiomilionowa i bogata Katalonia wpłaca więcej do budżetu centralnego i na fundusz solidarności międzyregionalnej niż dostaje z powrotem ${ }^{11}$. Katalończycy chcieliby także własnego systemu sądownictwa, samodzielnego sterowania systemem bankowym, ubezpieczeniami społecznymi. Również na te postanowienia rząd Zapatero nie chciał się zgodzić, gdyż albo łamią one konstytucyjną zasadę solidarności 17 wspólnot autonomicznych Hiszpanii, zgodnie z którą wspólnie ustala się podział władzy oraz pieniędzy między władze lokalne oraz rząd w Madrycie, albo rozbijają jedność rynku finansowego. Ostatecznie, w styczniu $2006 \mathrm{r}$. osiagnięto porozumienie z rządem w Madrycie, zgodnie z którym Katalonii przyznano prawo do ściagania ponad połowy podatków na swoim terytorium oraz otwarto drogę do utworzenia własnego urzędu podatkowego. Kontrowersyjny termin „naród kataloński” został wspomniany jedynie w preambule statutu, co według rządu centralnego ,nie ma konsekwencji prawnych”. Statut gwarantuje ponadto inwestycje publiczne w Katalonii proporcjonalnie do jej wkładu do budżetu państwa, prawo do zarządzania swoimi lotniskami oraz decydowania w sprawach imigracji (w tym wydawania zezwoleń na zatrudnienie). Zgodnie z propozycją rządu w Madrycie, nowy system finansowania ma zostać wprowadzony w pozostałych Wspólnotach Autonomicznych, co oznacza że większość podatków pozostawałaby w rękach tych Wspólnot. Komentatorzy zwracają jednak uwagę, że na reformie skorzystają przede wszystkim bogate autonomie, co z resztą podkreślił lider centroprawicowej PP, żądając przeprowadzenia ogólnonarodowego referendum w tej sprawie $^{12}$.

Również w Kraju Basków nastąiła eskalacja żądań autonomicznych, zwłaszcza od 29.12.2004 r., w którym parlament baskijski przyjął projekt (tzw. plan Ibarretxe), zmierzający do ustanowienia niezależnego państwa baskijskiego. Rządzący Krajem Basków od ustanowienia autonomii w 1979 r. umiarkowani nacjonaliści z Narodowej Partii Baskijskiej (PNV) sporządzili Plan już w 2002 r., a baskijski premier Juan Jose Ibarretxe podporządkował mu cały swój program polityczny. Plan przewidywał odrzucenie dotychczasowego statutu autonomicznego Kraju Basków, dającego lokalnemu rządowi i parlamentowi ogromne uprawnienia samorządowe

11 M. Stasiński, Katalonia rozsadza Hiszpanię, „Gazeta Wyborcza” z 3 października $2005 \mathrm{r}$.

12 Informacja PAP z 24 stycznia 2006 r., www.wiadomości.wp.pl. 
w niemal wszystkich dziedzinach, i zastapienie go nowym, ustanawiającym „wolne stowarzyszenie” Kraju Basków z Hiszpanią. Plan przyznawał narodowi baskijskiemu prawo do decydowania o swoim losie w drodze referendum, wprowadzał podwójną narodowość, baskijską i hiszpańską, własne sądownictwo oraz reprezentację Kraju Basków w Unii Europejskiej. Państwu hiszpańskiemu nowy statut przyznał natomiast prawo decydowania m.in. w sprawach azylu, obrony, posiadania broni, waluty, ceł, kontroli przestrzeni powietrznej i prawa karnego ${ }^{13}$. W lutym 2005 r. hiszpański parlament ogromną większością głosów odrzucił propozycję rządu baskijskiego, wobec czego premier Kraju Basków zapowiedział na kwiecień przedterminowe wybory samorządowe, będące $w$ istocie referendum w sprawie swojego planu ${ }^{14}$. Jednak oczekiwania Ibarretxe nie spełniły się. W kwietniowych wyborach rządząca autonomią Baskijska Partia Nacjonalistyczna (PNV) zdobyła co prawda najwięcej głosów, ale liczba posiadanych przez nią mandatów spadła z 33 do 29 w 75-osobowym parlamencie, a upragniona większość absolutna, za pomocą której chcieli wymusić na Madrycie rewizję statutu autonomicznego i przy okazji konstytucji Hiszpanii, wynosi 38 miejsc $^{15}$. Nie pozostało nic innego, jak negocjować zmianę statutu drogą kompromisów i ustępstw zarówno rządu centralnego, jak i Autonomii. Najbliższe wybory w Baskonii, wyznaczone na 1 marca 2009 r. pokażą, w jakim kierunku pójdzie polityka regionalnego rządu. Według sondaży przedwyborczych szansę na zwycięstwo ma zarówno PNV Juana Jose Ibarretxe, jak i socjaliści pod przywództwem Patxi Lopeza ${ }^{16}$. W przypadku wygranej tych drugich radykalne żądania nacjonalistów nie będą miały liczącej się politycznej reprezentacji, co przesunie dyskusję nad przyszłym kształtem relacji Kraju Basków i Państwa hiszpańskiego co najmniej o kilka lat.

Równie niepewne prognozy przedwyborcze dotyczą Galicji, w której $\mathrm{w}$ ciagu ostatnich kilku lat nasiliły się nastroje nacjonalistyczne. Wicepremier lokalnego rządu, Anxo Quintana w styczniu 2006 r. zwrócił się do

13 Maciej Stasiński, „Gazeta Wyborcza” z 30 grudnia 2004. Szczegóły Planu Ibarretxe dostępne na stronie: http://www.elmundo.es/documentos/2003/10/estatuto_vasco.pdf.

14 Informacja PAP z 2 lutego 2005 r., „Gazeta Wyborcza”.

15 M. Stasiński, Groźba rozwodu Basków z Hiszpaniq oddala się, „Gazeta Wyborcza" z 18 kwietnia 2005 r.

16 Informacja na stronie: http://www.elmundo.es/especiales/2009/02/espana/elecciones_autonomicas/pais_vasco/. 
rządu centralnego w Madrycie z żądaniem uznania „,narodu galicyjskiego". Quintana, będący jednocześnie rzecznikiem radykalnego Bloku Nacjonalistów Galicyjskich (BNG), zaapelował o uznanie dwustronnych relacji z Hiszpanią, autonomii finansowej regionu oraz programu spłacenia „historycznego długu” wobec Galicji. Apel Quintany związany był bezpośrednio $\mathrm{z}$ osiagnięciem porozumienia $\mathrm{w}$ sprawie rozszerzenia autonomii Katalonii ${ }^{17}$. Ogólny niepokój w tej sprawie powiększał fakt, że dowódca wojsk lądowych, generał Jose Mena Aguado w przemówieniu wygłoszonym podczas uroczystości wojskowej w Sewilli (w styczniu 2006 r.) zagroził interwencją wojska, jeżeli nowy statut Katalonii naruszy granice wyznaczone przez Konstytucję Hiszpanii „stojącej na straży jedności terytorialnej kraju". Minister obrony zareagował na tę wypowiedź wnioskiem o umieszczenie generała w areszcie domowym. Część kadry oficerskiej broniła jednak generała, twierdząc, że tej wypowiedzi „absolutnie nie można uważać za sprzeczną z regulaminem wojskowym"18. Jakkolwiek by nie było, sytuacja ta budzi nieprzyjemne skojarzenie z rokiem 1981, kiedy próba puczu wojskowego była m.in. związana z tworzeniem autonomii regionalnych.

Walka o poszerzenie autonomii i uznanie prawa do samostanowienia, wspólna dla Katalonii, Kraju Basków i Galicji stała się podstawą wspólnego działania tych trzech regionów, na mocy porozumienia trzech partii nacjonalistycznych (BNG, CiU oraz PNV) nazwanego GAULENSCAT (porozumienie polityczne na rzecz Państwa wielonarodowego). W lipcu 1998 r. partie te podpisały Deklarację z Barcelony, program polityczny, naznaczony - według firmujących go stron - przez proces zmian zachodzących w Europie na rzecz nowej redystrybucji władzy politycznej. Zgodnie z przedstawionym programem, GAULESCAT broni w Hiszpanii i Europie różnorodności narodowej i kulturalnej. Państwo hiszpańskie z jednej strony przedstawiane jest jako zagrożenie, tak długo jak odmawia Baskom, Katalończykom i Galicyjczykom pojęcia narodu i udziału bezpośredniego ,instytucji narodowych” na forum UE. Z drugiej strony

17 Po wyborach do parlamentu regionalnego Galicji w czerwcu 2005 r. po raz pierwszy od prawie ćwierćwiecza rządy objęła koalicja socjalistów z nacjonalistami galicyjskimi z BNG: Grażyna Opińska na podstawie informacji PAP z 23 stycznia 2006 r., www.wiadomości.wp.pl.

18 Grażyna Opińska, informacje PAP z 10 stycznia 2006 r., www.wiadomości.wp.pl. 
członkowie GAULESCAT uznają Państwo jako priorytetowy obszar politycznego działania ${ }^{19}$.

Pozostaje pytanie: co z tego wszystkiego wynika dla Europy, podlegającej ciagłemu procesowi integracji? Czy procesy zachodzące w Hiszpanii, możliwość radykalnej zmiany formy państwa można uznać za zagrożenie dla jednoczącej się Europy? Podkreślenia wymaga fakt, że europejskie partie regionalistyczne od początku lat 80-tych, czyli przyspieszenia procesu integracji, zaczęły artykułować swe roszczenia na forum międzynarodowym, w oczekiwaniu na ich spełnienie w formie autonomii terytorialnej czy pół-niezależności. Faktem jest, że UE wspiera decentralizację i chroni mniejszości etnolingwistyczne. Również faktem jest, że integracja i jednoczesna decentralizacja mogą osłabić państwa narodowe. Związane jest to z istnieniem idei Europy regionów, która od lat 80-tych uznana została za możliwy projekt polityczny i alternatywę dla „Europy Ojczyzn” de Gaulle’a czy obecnie „Europę Państw”. O ile pomysły demontażu państw narodowych są równie odległe co mało prawdopodobne, o tyle UE przyznaje regionom bardzo ważną rolę. Podkreśla się tym samym, że największe możliwości podejmowania decyzji demokratycznych znajdują się właśnie na poziomie regionalnym, umożliwiając obywatelom identyfikację regionalną. Jednocześnie w łonie UE istnieją głosy, przypominające o ryzyku izolacji i fragmentaryzacji, jako drugiej strony tego procesu.

Partie regionalne Europy podejmowały współpracę również w ramach UE. W 1981 r. powstał European Free Alliance (EFA), grupujący na początku 9 partii regionalnych. Obecnie jest ich 29, w tym nacjonalistyczne partie hiszpańskie (chociaż przez jakiś czas Baskowie i Katalończycy oponowali wobec planów współpracy z EFA, podkreślając że nie reprezentują interesów regionalnych, lecz narodowe). EFA walczy w łonie parlamentu europejskiego o zwiększenie roli regionów i ich współdecydowanie o przyszłości Europy, przeciwstawiając się budowie europejskiego superpaństwa $^{20}$. Zwraca uwagę fakt, że regiony hiszpańskie reprezentują w EFA partie najbardziej radykalne: BNG, ERC, czy Eusko Alkartasuna. Współpraca hiszpańskich regionów z innymi ma również miejsce $\mathrm{w}$ ramach Parlamentów Regionalnych Europy (CALRE), gdzie ostatnio parlamentarzyści Kraju Basków i Sycylii zaproponowali sojusz regionów

19 Program GAULESCAT, La alianza politica a favor de un estado plurinacional, dokument z 25 stycznia 2006 r., www.eaj-pnv.com.

20 B. Świderek, Wolny Sojusz Europejski, „Zakorzenienie” 2001, nr 1(13). 
o specjalnym statusie fiskalnym, w celu wspólnej obrony swoich interesów.

Hiszpańskie partie regionalne są również reprezentowane w Parlamencie Europejskim. Baskijska Partia Nacjonalistyczna, Republikańska Lewica Katalonii, Nacjonalistyczny Blok Galicji i Partia Aragońska należą do grupy politycznej Zielonych - Wolnego Sojuszu Europejskiego, reprezentującego „narody bez państw” (chociaż jeden z członków PNV, Josu Ortuondo Larrea należy do Partii Porozumienia Liberałów i Demokratów na rzecz Europy). W wyborach z 2004 r. koalicja GALEUSCA uzyskała bardzo słaby wynik wyborczy (niewiele ponad 5\% głosów), zdobywając jedynie 3 mandaty $^{21}$.

Regiony hiszpańskie, obok innych regionów europejskich, podjęły nadto bardzo ważną inicjatywę. Aby móc bezpośrednio reprezentować swoje interesy przed instytucjami europejskimi od połowy lat 80-tych zaczęły tworzyć własne biura w Brukseli. Działo się to wbrew woli rządu centralnego, dopiero wyrok Trybunału Konstytucyjnego z 1995 r. zalegalizował te działania. Równocześnie, wewnątrz Wspólnot Autonomicznych powstały jednostki odpowiedzialne za kontakty z Unią, co z kolei zapoczątkowało rodzaj polityki zagranicznej regionów, bez pośrednictwa odpowiednich ministerstw centralnych, w celu ustanowienia relacji z innymi regionami oraz instytucjami europejskimi. ,Reprezentacja regionalna" jest obecnie uznawana przez organizmy wspólnotowe. Legitymizacja regionów jako aktorów politycznych procesu integracji europejskiej została osiagnnięta. Traktat z Maastricht podkreślał, że „Droga do Europy prowadzi przez regiony”, tak więc istnienie rządów lokalnych zostało uznane w ramach Wspólnoty. W ten sposób doszło do utworzenia Komitetu Regionów, stanowiącego oficjalny organ Unii, obok Rady Ministrów i Parlamentu. Przedstawiciele regionów domagali się, by Komitet przekształcił się w trzecią siłę Unii, lub jak niektórzy twierdzą Senat Europy; izbę reprezentacji regionalnej. Taka zmiana zaspokoiłaby żądania większość regionów, sprawiając że Komitet stałby się trzecim poziomem architektury europejskiej, obok Europy Państw Narodowych.

$\mathrm{Z}$ powyższych faktów wynika, że nacjonalizmy istniejące wewnątrz Hiszpanii, przejawiając cechy separatystyczne, przychylnie odnoszą się do procesu integracji europejskiej, która daje szanse na pełniejszą artyku-

21 X. M. Pereiro, El Constitucional desestima El resurso de Galeusca por la atribucion de un eurodiputado al. PP, „El Pais” z 13 sierpnia 2004 r. 
lację tendencji i dążeń wolnościowych. Można nawet zaryzykować tezę, zgodnie z którą to właśnie dzięki zacieśnieniu więzi europejskich, niejako ponad państwem, udało się spełnić część roszczeń i myśleć o dalszych. „No” dla Hiszpanii oznacza zatem często „si” dla Europy. Otwarte pozostaje pytanie o pożądany przez nacjonalistów kształt Wspólnej Europy, przy czym przydatną wskazówką okazał się stosunek poszczególnych partii regionalnych do Konstytucji Europejskiej, poddanej pod referendum w lutym 2005 r. Za traktatem opowiedziały się wówczas: katalońska CiU i baskijska PNV, przeciw natomiast: katalońska Republikańska Lewica Katalonii (ERC), galicyjska BNG i baskijska Eusko Alkartasuna. Begońa Errazti, przewodnicząca Eusko Alkartasuna argumentowała, że Konstytucja „nie uznaje istnienia narodów bez państwa i pluralizmu narodowościowego", gdyż nie zawiera prawa do samostanowienia narodów, określając tylko pojęcie Państwa, a w kwestiach socjalnych ,jest sprzeczna z koncepcją europejskiego Państwa dobrobytu", której broni jej ugrupowanie. Zaznaczyła też, że projekt konstytucji zakłada homogenizację państw, „Europę jakiej nie chcemy” w ramach Wolnego Sojuszu Europejskiego, do którego należy EA, i który broni „Europy Narodów”22. Inni przeciwnicy Konstytucji przedstawiali podobne argumenty. Trudno zrozumieć różnicę zdań między przeciwnikami i zwolennikami Konstytucji Europejskiej, zwłaszcza że żądanie samostanowienia wysuwane wobec Państwa hiszpańskiego łączy te trzy wspólnoty autonomiczne. PNV, ustami swojego przedstawiciela w PE Josu Ortuondo Larrea (PNV), wskazało, że głos na „tak” w referendum osłabi, lub nawet zniweluje kampanie demagogiczne przeciwko planowi Ibarretxe, zgodnie z którymi plany lehendakari oddalają Hiszpanię od Europy. Uznać zatem można, że „tak” PNV miało charakter czysto koniunkturalny, związany z intensywną kampanią na rzecz planu Ibarretxe.

Warto na koniec przypomnieć inną wizję Europy, którą przedstawiciele PNV dzielili się podczas Konferencji „Europa 100 Flag - różnorodność a integracja”, która miała miejsce w Katowicach 23 lutego 1999 r. Baskowie z tego ugrupowania podpisali się pod koncepcją federalizmu europejskiego, „Europy 100 Flag” stworzonej przez nacjonalistę bretońskiego Yanna Fouere. Według autonomistów przyszła Europa powinna być federacją autonomicznych regionów, respektujących uwarunkowania etnicz-

22 Informacje na stronie:

http://www.noticias.info/archivo/2004/200408/20040818/20040818_31001.shtm. 
no-kulturowe. Sprzeciwiają się oni zarówno koncepcji europejskiego superpaństwa, jak i wspólnoty państw narodowych, które uważają za swego największego wroga. Foure pisał: „Europa dużych państw [...] nie jest i nigdy nie była Europą naturalną. [...] Prawdziwa Europa, naturalna, składa się z wielu małych państewek, wielu wspólnot narodowych, okręgów i wolnych miast, które łączy ponad podziałami i odmiennościami wspólna cywilizacja wykuwana od dwóch milleniów ${ }^{23}$. Autonomiści widzą więc Europę jako swoisty zlepek regionów, będących alternatywą dla skostniałych struktur państw narodowych. Tym bardziej dziwi poparcie PNV dla Konstytucji Europejskiej, której przyjęcie uniemożliwiłoby realizację przedstawionej wyżej idei. Wynikać to może z braku jasnej koncepcji przyszłego kształtu Europy. Nie zmienia jednak faktu, że to właśnie Europa, bardziej aniżeli Państwo hiszpańskie, jest w stanie zapewnić realizację marzeń o niezależności.

\section{Summary}

The term 'Common European Home' was coined in 1987 by Mikhail Gorbachev to describe the future policy of the Soviet Union towards Eastern Europe. At present this notion has lost its disquieting tone, which was related to the statement made by the Soviet Political Bureau: 'a stifling embrace, a suffocating hug'. Nowadays, this idea covers various models of European integration, and is expressed in both the hopes and concerns of the states that participate in this process. The economic and political integration of European states has been a continuous and dynamic process. The question of its further direction has become particularly important after the French said 'non' to the European Constitution. This has refueled disputes over existing integration models, which are focused around the opposing concepts of a Federal Europe and a Europe of Homelands as a confederation. It is of significant importance since the process of Europeization has been parallel to the process of regionalization inside the national European states. Regionalization mainly followed from the demands of autonomists, but sometimes was initiated by central governments as part of the process of decentralization. At present, European regions have increased their economic significance and have won more rights and authority inside their states. Consequently, they have aspired to become independent forces for globalization and Europeization. This process can be exemplified by Spain. After forty years of Franco's dictatorship, where any form of regional autonomy whatsoever was rejected, in 1975 a slow democratization process began.

${ }^{23}$ B. Świderek, Europa 100 Flag, „Zakorzenienie” 1999, nr 4(6). 